\title{
Vocabulary Learning Strategies of Thai University Students and Its Relationship to Vocabulary Size
}

\author{
Supika Nirattisai (Corresponding author) \\ M.A. student, Department of Languages and Linguistics, Faculty of Liberal Arts \\ Prince of Songkla University, Hat Yai Campus, Songkla, Thailand \\ E-mail: supika_mew@hotmail.com
}

\begin{abstract}
Thanyapa Chiramanee
Assoc. Prof. Dr., Department of Languages and Linguistics, Faculty of Liberal Arts

Prince of Songkla University, Hat Yai Campus, Songkla, Thailand

E-mail: thanyapa.c@psu.ac.th
\end{abstract}

Received: March 12, 2014 Accepted: March 25, 2014 Published: March 25, 2014

doi:10.5296/ijele.v2i1.5366 URL: http://dx.doi.org/10.5296/ijele.v2i1.5366

\begin{abstract}
The present study aimed to investigate vocabulary learning strategies employed by Thai university students. The relationship between the students' vocabulary learning strategies and their vocabulary size was also explored. The subjects of this study were 257 Prince of Songkla University students in the 6 fields of study: medicine, dentistry, nursing, engineering, accounting, hospitality and tourism which will be highly affected by the forthcoming ASEAN Economy Community (AEC) in 2015. The research data were obtained from 2 instruments: the vocabulary learning strategy questionnaire and the bilingual English-Thai version of vocabulary size test. The study revealed that the subjects slightly employed the overall vocabulary learning strategies. Out of 39 vocabulary learning strategies, the subjects employed 2 strategies at a high level, 18 strategies at a moderate level, and 19 strategies at a low level. The subjects' use of the overall vocabulary learning strategies was moderately correlated with their vocabulary size. Seventeen vocabulary learning strategies were correlated with their vocabulary size at a moderate degree while the rest at a low degree.
\end{abstract}

Keywords: Vocabulary learning strategies, vocabulary size, Thai university students 


\section{Introduction}

English is a common language in many different fields including business and education (Crystal, 1997). No one denies the prominence of English language in the present time as a universal language. With the effect of AESAN Economic Community (AEC) in 2015, English will increasingly become more important for member countries' workers in terms of employment opportunities, especially Thais, whose English proficiency was founded to be at "a very low proficiency level" according to the EF English Proficiency Index (EF EPI, 2013). In order to take the benefit of this open trade, Thai workers need to have an adequate English proficiency for communication.

English proficiency has been found to be closely related to vocabulary knowledge (e.g., Laufer, 1998; Nation and Meara, 2002). This strong relationship can be explained by the role of vocabulary in language learning. Vocabulary is considered as a very essential component of any languages (Waring and Nation, 1997). To be able to achieve high language performance, learners need large and rich vocabulary repertoire to use language effectively (McCarthy, 1990 and 1998). Lack of vocabulary obstructs learners' language development as a higher language level requires a higher amount of words (Waring and Nation, 1997, Hu and Nation, 2000). Nandy (1994) asserts that "The more words one is able to use correctly, the better one will be able to express oneself easily and with self-confidence and to understand the world one lives in" (p. 1). Insufficient vocabulary emerges as a major problem among L2 learners, including Thai learners, causing their poor language performance in 4 skills: reading, listening, speaking, and writing skills (Sawangwarorose, 1984 and Sukkrong, 2010).

Consequently, in recent years many researchers have paid more attention on finding ways to develop learners' vocabulary level. Using vocabulary learning strategies is one of effective tools to enhance learners' vocabulary size (e.g., Cunningsworth, 1995; Nation, 2001). According to Nation (2001), large vocabulary can be acquired with the help of vocabulary learning strategies and they are useful for learners in all language proficiencies. Cunningworth (1995) also stated that helping learners develop their vocabulary learning strategies is a powerful approach to help learners acquire large vocabulary repertoire.

The main advantage of vocabulary learning strategies is that they allow learners to take more control of their own learning (Scharle and Szabo, 2000; Nation, 2001) and also develop "learner autonomy, independence, and self-direction" (Oxford and Nyikos, 1989, p. 291). A number of scholars, for example, Gairns and Redman (1986) and Sokmen (1997), have recognized the importance of learners' independence in vocabulary learning. According to Gairns and Redman (1986), after the elementary level where students are provided with plenty of new English words in class, it is difficult for teachers to select all useful words to them, so learners must have more responsibilities for their own learning of vocabulary. Sokmen (1997) believes that it is impossible for learners to remember all words they need in class and to acquire large vocabulary they need to take responsibilities for their own learning.

As discussed above, vocabulary learning strategies have been shown to help learners develop their vocabulary knowledge. Thus, it is worthwhile to study vocabulary learning strategies used by Prince of Songkla University students and to see the relationship between vocabulary 
learning strategies and the students' vocabulary size.

\section{Literature Review}

\subsection{Definition and Classification of Vocabulary Learning Strategies}

Vocabulary learning strategies are considered a part of language learning strategies (Nation, 2001). For Cameron (2001), vocabulary learning strategies are "the actions that learners take to help themselves understand and remember vocabulary items" (p. 92). Catalan (2003), based on Rubin's (1987), Wenden's (1987), Oxford's (1990), and Schmitt's (1997) definition, defines vocabulary learning strategies as "the mechanism used in order to learn vocabulary as well as steps or actions taken by students (a) to find out the meaning of unknown words, (b) to retain them in long-term memory, (c) to recall them at will, and (d) to use them in oral or written mode" (p. 56). According to Intaraprasert (2004), vocabulary learning strategies are "any set of techniques or learning behaviors, which language learners reported using in order to discover the meaning of new word, to retain the knowledge of newly-learned words, and to expand one's knowledge of vocabulary" (p. 53).

Many classifications of vocabulary learning strategies have been proposed by scholars (e.g., Oxford, 1990; Gu and Johnson, 1996; Schmitt, 1997). Among these classifications, one of the well-known and well-accepted among researchers (e.g., Hamzah and Kafipour and Abdulla, 2009; Sripetpun, 2000) is that by Schmitt (1997) who divides vocabulary learning strategies into 5 sub-categories: (1) memory strategies - connecting a new word with formerly learned knowledge, (2) cognitive strategies - similar to memory strategies but focusing on manipulative mechanical process, (3) metacognitive strategies - processes of learning and making decisions about planning, monitoring, and evaluating the best way to study, (4) determination strategies - used by individual to discover a word's meaning without consulting other people, and (5) social strategies - a way to learn a new word by interacting with other people.

\section{Research Questions}

1. What is the frequency of vocabulary learning strategy used by Prince of Songkla University students?

2. What are the relationships between vocabulary learning strategies and vocabulary size?

\section{Methodology}

\subsection{Subjects}

The subjects of this study were 257 Prince of Songkla University students in the 6 fields of study which will be highly affected by the opening of ASEAN Economy Community (AEC). These 257 subjects were 39 from medicine, 29 from dentistry, 48 from nursing, 90 from engineering, 25 from accounting, and 26 from hospitality and tourism. 


\subsection{Research Instruments}

\subsubsection{Vocabulary Learning Strategy Questionnaire}

The purpose of this questionnaire was to investigate students' frequency of vocabulary learning strategy use. The questionnaire was adapted from that of Schmitt (1997) and Siriwan (2007). The reliability coefficient of this questionnaire was .92. All 39 items in the questionnaire were divided into 5 main categories of vocabulary learning strategies: 11 items in memory category, 5 items in cognitive category, 9 items in metacognitive category, 7 items in determination category, and 7 items in social category. The rating scale covered six numbers ranging from 0 (never) to 5 (always).

The interpretation of ratings in the questionnaire was based on Best (1981). Scores $0-1.5$ indicate as a very low use, $1.50-2.49$ as a low use, $2.50-3.49$ as a moderate use, $3.50-$ 4.49 as a high use, and $4.50-5.00$ as a very high use.

\subsubsection{The Bilingual English-Thai Version of Vocabulary Size Test}

The bilingual version of vocabulary size test adopted from the monolingual English version of vocabulary size test by Nation and Beglar (2007) was used to measure students' vocabulary size. This bilingual version test was a multiple-choice format consisting of 14th 1000 word levels with a total of 140 items - there were 10 items from each 1000 word level. In this test, learners were asked to choose the closest definition to the target word. Here is an example, item 45 from the 5 th 1000 word level.

45. compost: We need some compost.
a. การสนับสนุนช่วยเหลืออย่างเต็มที่
b. ช่วยให้รู้สึกดีขึ้น
c. วัสดุแข็งทำขึ้นจากหินและดินทรายผสมกัน
d. สิ่งที่เกิดจากการเน่าเปื่อยของพืช
e. ไม่ทราบคำตอบ

To estimate students' vocabulary size, their total scores from the bilingual English-Thai version of vocabulary size test need to be multiplied by 100. If a student scores 35 out of 140, their vocabulary size will be 3500 word families (Nation and Beglar, 2007).

\subsection{Data Collection}

The vocabulary learning strategy questionnaire and the bilingual English-Thai version of vocabulary size test were distributed after the research purposes were explained to 257 subjects. Then, the subjects completed these 2 research instruments.

\subsection{Data Analysis}

To answer the first research question, descriptive statistics was used to compute the mean and standard deviations of the subjects' use of vocabulary learning strategies. To answer the second research question, Pearson correlation was applied to test the relationship between vocabulary learning strategies and vocabulary size. 


\section{Results}

Research Question 1: What is the frequency of vocabulary learning strategy used by Prince of Songkla University students?

The frequency of vocabulary learning strategy use reported by 257 Prince of Songkla University students is presented in Table 1.

Table 1. Frequency of vocabulary learning strategy use

\begin{tabular}{cccc}
\hline Strategies & Mean & S.D. & Level of use \\
\hline Determination & 2.80 & 1.02 & Medium \\
\hline Metacognitive & 2.58 & 1.06 & Medium \\
\hline Memory & 2.43 & 0.97 & Low \\
\hline Cognitive & 2.37 & 1.07 & Low \\
\hline Social & 2.29 & 0.98 & Low \\
\hline Overall strategies & 2.49 & 0.91 & Low \\
\hline
\end{tabular}

In Table 1, Prince of Songkla University subjects used the overall vocabulary learning strategies at a low level with the mean score of 2.49 (S.D. = 0.91). In other words, the students were found to be low strategy users for the overall vocabulary learning strategies.

Determination strategies were the most frequently used strategies by the students (mean = 2.80, S.D. $=1.02)$, followed by metacognitive strategies $($ mean $=2.58$, S.D. $=1.06)$, memory strategies $($ mean $=2.43$, S.D. $=0.97)$, cognitive strategies $($ mean $=2.37$, S.D. $=1.07)$, and social strategies (mean $=2.29$, S.D. $=0.98)$, respectively. In terms of levels of use, the subjects employed the determination and metacognitive strategies at a moderate level while memory, cognitive, and social strategies at a low level.

There were a total of 39 vocabulary learning strategies under the 5 above-mentioned strategy categories. The subjects employed 39 strategies at different degrees: a high degree, a moderate degree, and a low degree.

Table 2 shows the vocabulary learning strategies which were highly employed by the subjects.

Table 2. The high frequently used strategies

\begin{tabular}{clccc}
\hline No. & \multicolumn{1}{c}{ Strategies } & Category & Mean & S.D. \\
\hline 1 & Look up words in an English-Thai dictionary & Determination & 3.56 & 1.19 \\
\hline 2 & Listen to English songs & Metacognitive & 3.55 & 1.35 \\
\hline
\end{tabular}

As table 2 displays, there were only 2 out of 39 vocabulary learning strategies which were 
highly used by the subjects and these 2 strategies were "listen to English songs" (Item 1) in metacognitive category, and "look up a word in an English-Thai dictionary" (Item 2) in determination category.

The vocabulary learning strategies moderately employed by the subjects are shown in Table 3.

Table 3. The moderate frequently used strategies

\begin{tabular}{clccc}
\hline No. & \multicolumn{1}{c}{ Strategies } & Category & Mean & S.D. \\
\hline 3 & Use English websites & Metacognitive & 3.41 & 1.41 \\
\hline 4 & Watch English television programs / English films & Metacognitive & 3.21 & 1.54 \\
\hline 5 & Learn words through verbal repetition & Cognitive & 3.00 & 1.13 \\
\hline 6 & Ask classmates to translate the meanings of words & Social & 2.98 & 1.24 \\
\hline 7 & Guess the meanings of words from textual context & Determination & 2.96 & 1.32 \\
\hline 8 & Learn words through written repetition & Cognitive & 2.86 & 1.23 \\
\hline 9 & Look up words in a Thai-English dictionary & Determination & 2.85 & 1.23 \\
\hline 10 & Say words aloud when studying & Memory & 2.82 & 1.26 \\
\hline 11 & $\begin{array}{l}\text { Analyze affixes and roots to guess the meanings of } \\
\text { words }\end{array}$ & Determination & 2.80 & 1.39 \\
\hline 12 & Make a group of words by topic for reviewing & Memory & 2.77 & 1.12 \\
\hline 13 & $\begin{array}{l}\text { Analyze parts of speech to guess the meanings of } \\
\text { words }\end{array}$ & Determination & 2.77 & 1.37 \\
\hline 14 & Study words with pictures & Memory & 2.75 & 1.07 \\
\hline 15 & $\begin{array}{l}\text { Analyze any available pictures or gestures } \\
\text { understand the meanings of words }\end{array}$ & Determination & 2.74 & 1.31 \\
\hline 16 & $\begin{array}{l}\text { Translate the meanings of words from English into } \\
\text { Thai }\end{array}$ & Metacognitive \\
\hline 17 & Use English printed matter & & & \\
\hline 18 & Play vocabulary games & Metacognitive & 2.72 & 1.24 \\
\hline 19 & Associate the word with other words you have learned & Metacognitive & 2.62 & 1.40 \\
\hline 20 & Connect words to personal experiences & Memory & 2.59 & 1.34 \\
\hline
\end{tabular}

In Table 3, of these 18 vocabulary learning strategies which were moderately employed by the subjects, 5 strategies were in memory category (Items 10, 12, 14, 19, and 20), 5 strategies in metacognitive category (Items 3, 4, 16, 17, and 18), 5 strategies in determination category (Items 7, 9, 11, 13, 15, and 17), 2 strategies in cognitive category (Items 5 and 8), and 1 strategy in social category (Item 6).

The strategies slightly employed by the subjects are displayed in Table 4. 
Table 4. The low frequently used strategies

\begin{tabular}{clccc}
\hline No. & \multicolumn{1}{c}{ Strategies } & Category & Mean & S.D. \\
\hline 21 & $\begin{array}{l}\text { Remember the word from its "root", "prefix", and } \\
\text { "suffix" }\end{array}$ & Memory & 2.41 & 1.38 \\
\hline 22 & Discover new meanings through group work activities & Social & 2.40 & 1.21 \\
\hline 23 & Connect the word to its synonyms and antonyms & Memory & 2.38 & 1.24 \\
\hline 24 & Ask teachers to translate the meanings of words & Social & 2.35 & 1.28 \\
\hline 25 & Translate the meanings of the words from Thai into & Metacognitive & 2.30 & 1.30 \\
& English & & & \\
\hline 26 & Look up words in an English-English dictionary & Determination \\
\hline 27 & Test yourself with word tests & Metacognitive & 2.25 & 1.33 \\
\hline 28 & Learn words of an idiom together & Memory & 2.23 & 1.30 \\
\hline 29 & Make a group of words by alphabetical order for & Memory & 2.17 & 1.45 \\
& reviewing & & & \\
\hline 30 & Listen to a tape of word lists & Cognitive & 2.14 & 1.27 \\
\hline 31 & Keep a vocabulary notebook wherever you go & Cognitive & 2.14 & 1.34 \\
\hline 32 & Interact with classmates & Social & 2.19 & 1.29 \\
\hline 33 & Use words in sentences & Memory & 2.09 & 1.23 \\
\hline 34 & Stick the word and its meaning in a place where it can & Memory & 2.03 & 1.38 \\
& be obviously seen & & & \\
\hline 35 & Interact with an English teacher & Social & 1.95 & 1.42 \\
\hline 36 & Ask other people to translate the meanings of words & Social & 1.97 & 1.36 \\
\hline 37 & Interact with native English speakers & Social & 1.94 & 1.36 \\
\hline 38 & Study words over time & Metacognitive \\
\hline 39 & Use vocabulary flashcards & 1.88 & 1.19 \\
\hline & & Cognitive & 1.70 & 1.41 \\
\hline
\end{tabular}

From these 19 vocabulary learning strategies slightly used by the subjects, 6 strategies belong to memory category (Items 21, 23, 28, 29, 33, and 34), 6 strategies belong to social category (Items 22, 24, 32, 35, 36, and 37), 3 strategies belong to cognitive category (Items 30, 31, and 39), 3 strategies belong to metacognitive category (Items 25, 27, and 38), and 1 strategy belongs to determination category (Item 26).

Research Question 2: What are the relationships between vocabulary learning strategies and vocabulary size?

The correlations between the 257 subjects' use of vocabulary learning strategies and their vocabulary size are shown in Table 5. The interpretation of the correlation coefficient was based on Ratner (2011). The values 0 to 0.3 indicate a weak relationship, 0.3 to $0.7 \mathrm{a}$ moderate relationship, and 0.7 to 1.0 a strong relationship. 
Table 5. Relationship between vocabulary learning strategies and vocabulary size

\begin{tabular}{cccc}
\hline Strategies & $\mathrm{r}$ & Sig & Level of correlation \\
\hline Metacognitive & .395 & $.000^{* *}$ & Moderate \\
\hline Memory & .373 & $.000^{* *}$ & Moderate \\
\hline Determination & .355 & $.000^{* *}$ & Moderate \\
\hline Social & .333 & $.000^{* *}$ & Moderate \\
\hline Cognitive & .275 & $.000^{* *}$ & Weak \\
\hline Overall & .388 & $.000^{* *}$ & Moderate \\
\hline
\end{tabular}

** Significant at the .01 level

As shown in Table 5, the correlation between the subjects' use of the overall vocabulary learning strategies and their vocabulary size was significant at a moderate level $(r=0.388, p$ <.01). In other words, subjects with high frequency of vocabulary learning strategy use had greater vocabulary repertoire, and vice versa, indicating that the higher use of vocabulary learning strategies leads subjects to the greater vocabulary size.

The 4 strategy categories: metacognitive, memory, determination, and social strategies were correlated with vocabulary size at a moderate level $(\mathrm{r}=.395, .373, .355$, and .333), respectively; metacognitive strategies had the highest correlation among them. Only cognitive strategies were correlated with vocabulary size at a weak level $(r=.275)$.

The relationships between 39 vocabulary learning strategies and vocabulary size were at two different levels: a moderate level and a low level. Table 6 shows the vocabulary learning strategies which have a moderate contribution to the subjects' vocabulary size.

Table 6 . The vocabulary learning strategies which moderately contributed to the students' vocabulary size

\begin{tabular}{clccc}
\hline No. & \multicolumn{1}{c}{ Strategies } & categories & $\mathrm{r}$ & Sig \\
\hline 1 & $\begin{array}{l}\text { Remember the word from its "root", "prefix", and } \\
\text { "suffix" }\end{array}$ & Memory & .414 & $.000^{* *}$ \\
\hline 2 & Guess the meanings of words from textual context & Determination & .397 & $.000^{* *}$ \\
\hline 3 & Analyze affixes and roots to guess the meaning of words & Determination & .388 & $.000^{* *}$ \\
\hline 4 & Learn words through verbal repetition & Cognitive & .386 & $.000^{* *}$ \\
\hline 5 & Use English printed matter & Metacognitive & .386 & $.000^{* *}$ \\
\hline 6 & Analyze parts of speech to guess the meanings of words & Determination & .371 & $.000^{* *}$ \\
\hline 7 & Learn words of an idiom together & Memory & .357 & $.000^{* *}$ \\
\hline 8 & $\begin{array}{l}\text { Associate the word with other words you have } \\
\text { learned }\end{array}$ & Memory & .354 & $.000^{* *}$ \\
\hline
\end{tabular}

** Significant at the .01 level 
Table 6. (Continued)

\begin{tabular}{clccc}
\hline No. & \multicolumn{1}{c}{ Strategies } & categories & $\mathrm{r}$ & Sig \\
\hline 9 & Watch English television programs / English films & Metacognitive & .346 & $.000^{* *}$ \\
\hline 10 & Use English websites & Metacognitive & .344 & $.000^{* *}$ \\
\hline 11 & Connect the word to its synonyms and antonyms & Memory & .338 & $.000^{* *}$ \\
\hline 12 & Listen to English songs & Metacognitive & .335 & $.000^{* *}$ \\
\hline 13 & Connect words to personal experiences & Memory & .332 & $.000^{* *}$ \\
\hline 14 & Learn words through written repetition & Cognitive & .318 & $.000^{* *}$ \\
\hline 15 & Use vocabulary flashcards & Cognitive & .316 & $.000^{* *}$ \\
\hline 16 & Interact with English teachers & Social & .352 & $.000^{* *}$ \\
\hline 17 & Play vocabulary games & Metacognitive & .305 & $.000^{* *}$ \\
\hline
\end{tabular}

** Significant at the .01 level

In Table 6, 17 out of 39 vocabulary learning strategies were correlated with the subjects' vocabulary size at a moderate level: the strategy "remember the word from its root, prefix, and suffix" had the highest correlation with the subjects' vocabulary size; the strategies "guess the meanings of words from textual context" and "analyze affixes and roots to guess the meaning of words" had the second and the third highest correlation. The rest of the other strategy items were correlated with the subjects' vocabulary size at a weak level.

It should be noted that among these 17 strategies, only one social strategy "interact with English teachers" was found to be moderately correlated with the subjects' vocabulary size while the others were slightly correlated with their vocabulary size.

\section{Conclusion}

The findings of the present investigation are summarized as follows:

1. Prince of Songkla University subjects employed the overall vocabulary learning strategies at a low level. The most frequently used strategies were determination strategies, followed by metacognitive strategies, memory strategies, cognitive strategies, and social strategies, respectively. Among 39 vocabulary learning strategies, the subjects highly used 2 strategies, moderately used 18 strategies, and slightly used 19 strategies.

2. The overall use of vocabulary learning strategies was moderately correlated with the subjects' vocabulary size. Seventeen out of 39 vocabulary learning strategies were correlated with vocabulary size at a moderate level while the rest of the strategy items at a low level.

\section{Discussion}

The finding that the subjects employed the overall vocabulary learning strategies at a low level is consistent with previous studies (Hamzah and Kafipour and Abdulla, 2009; Asgari and Mustapha, 2011) which found that L2 learners tend not to highly employ vocabulary learning strategies. The subjects' low frequency of vocabulary learning strategy use may be due to the low attention on teaching and learning vocabulary. Carter and McCarthy (1988), 
Fan (2003), and Siriwan (2007) stated that in Asean countries including Thailand, vocabulary is usually given little emphasis in teaching and learning context; the focus is mostly on reading, listening, speaking, and writing skills. As a result, teachers do not pay attention to introducing students to various learning techniques or strategies to develop vocabulary knowledge, making students unfamiliar with many vocabulary learning strategies and lead to their low frequency of use.

Moreover, English learning in Thai context is primarily a teacher-centered approach. In this learning environment, students rely heavily on teachers and slightly on themselves (Rattanavich, 2013). It seems that teacher-centered approach makes Thai students take fewer responsibilities or initiations of their own learning and this could impact students' low level of vocabulary learning strategy use. According to Oxford and Nyikos (1989), vocabulary learning strategies are methods that allow learners to enhance their learning autonomy, independence, and self-direction so the level of vocabulary learning strategy use highly depend on students themselves. Students with more control of their own learning will employ strategies more frequently.

Among 5 main strategy categories, the subjects reported that determination strategies were the most frequently used strategies and social strategies were the least used strategies. This finding is in line with several studies (e.g., Sarani and Kafipour, 2008; Komol and Sripetpun, 2011) which supported that learners are interested in using determination strategies more than other strategy categories and the social strategies were generally found the least use among L2 learners. The least use of social strategies may be because Thai educational university curriculum does not provide much social learning context. Thai university teachers generally adopted the more traditional teacher-centered or lecture-based approach in classroom (Rattanavich, 2013); the activities in class are mostly centered on teachers and students only follow the teachers' instructions. Thus, students would have fewer opportunities to use social strategies such as discussion or group work in their learning, including vocabulary learning.

The finding that there was a moderate relationship between the overall vocabulary learning strategies and vocabulary size is in agreement with many scholars, e.g., Gu and Johnson (1996) Komol \& Sripetpun (2011), and Waldvogel (2011), who supported that the use of vocabulary learning strategies seems to relate to learners' vocabulary knowledge. In the other words, students with high frequently use of vocabulary learning strategies have greater vocabulary size, and vice versa.

Among 17 vocabulary learning strategies with a moderate contribution to vocabulary size, only one strategy "listen to English songs" was highly employed by the subjects. The high level of use of this strategy may be because songs are readily available and easy to access. Moreover, the researchers such as Bada and Okan (2000), Ghada et al. (2011) found that L2 students have highest preference for auditory learning and listening to songs is one of the activities that students prefer.

Interestingly, the subjects reported employing the strategy "look up a word in an English-Thai dictionary" at a high degree while this strategy only slightly contributed to their vocabulary size. The finding about the high use of this strategy is in line with Schmitt (1997) who found 
that L2 learners utilize a bilingual dictionary as a useful resource in learning vocabulary and they often consult a bilingual dictionary when they encounter unfamiliar words. However, Komol and Sripetpun's (2011) revealed that Thai university students tend to have problem with finding the right words from an English-Thai dictionary. Thus, this problem might explain the low contribution of this strategy to learners' vocabulary size.

The subjects moderately employed 11 out 17 effective vocabulary learning strategies. These strategies were "analyze parts of speech to guess the meanings of words", "analyze affixes and roots to guess the meanings of words", "learn words through verbal repetition", "use English printed matter", "guess the meanings of words from textual context", "associate the word with other words you have learned", "watch English television programs / English films", "use English websites", "connect word to personal experiences", "learn words through written repetition", and "play vocabulary games".

The subjects slightly used 5 out of 17 high effective vocabulary learning strategies. They were "remember the word from its root, prefix, and suffix", "learn words of an idiom together", "connect the word to its synonyms and antonyms", "use vocabulary flashcards", and "interaction with English teachers".

It is interesting that although the strategy "remember the word from its root, prefix, and suffix" was the most important contribution to students' vocabulary size compared to other vocabulary learning strategies, it was slightly employed by the subjects. The low frequency of use may be because students had difficulty with identifying word parts or were not taught to make use of roots, prefixes, and suffixes. There are three types of word parts: prefixes, roots, and suffixes which put together to create a thousand of words. The knowledge of word parts will help students to remember unknown words. However, it is not easy to unlock them. This is because there are a number of prefixes, suffixes in English language and some word parts are not recognized by students. Moreover, the prefixes and suffixes of some words are hardly identified such as the words decode (de + code), relative (relate + tive). Laufer $(1990)$ and Kocic (2008) also found that suffix synforms tended to be major problems for L2 learners. Thus, this strategy needs to be effectively taught to students.

The findings that the subjects employed many vocabulary learning strategies at a low level might not be due to the fact that they did not realize the contribution of vocabulary learning strategies to their vocabulary knowledge. Although, a number of studies on vocabulary learning strategies have been conducted in Thailand, the findings about their significant roles are not known to general learners. In addition, vocabulary learning is not a subject in school itself; students learn vocabulary as a part of other skills such as reading, listening, writing, and speaking. In other words, vocabulary is not explicitly taught as a subject. Students learn them as assigned in their other language subjects or even expected to acquire incidentally or their own.

As a result, teachers should realize how and what important vocabulary learning strategies are and encourage learners to apply them in vocabulary learning. Students themselves need to be informed of the benefits of vocabulary learning strategies, to know their limitation in using vocabulary learning strategies, and to take more responsibility for their own vocabulary 
learning. The use of vocabulary learning strategies can lead students to large vocabulary size. According to McCarthy (1990) and Hu and Nation (2000), insufficient vocabulary knowledge will obstruct students to achieve high language performances of 4 skills: reading, listening, writing, and speaking, thus students need the high vocabulary size to use language effectively.

\section{Further Studies}

This study aimed to examine the vocabulary learning strategies of Prince of Songkla University students. More research should be done with various groups of university students to better understand the roles of vocabulary learning strategies. In addition to using the questionnaire, further studies should include other methods such as interview, observation, journal writing in order to get in-depth information about students' use of vocabulary learning strategies. This may also allow researchers to discover further aspects such as students' attitudes towards learning English, students' problems with the use of vocabulary learning strategies, etc.

\section{References}

Asgari, A. \& Mustapha, G.B. (2011). The type of vocabulary learning strategies used by ESL students in University Putra Malaysia. English language Teaching, 4(2), 84-90. http://dx.doi.org/10.5539/elt.v4n2p84

Bada, E. \& Okan, Z. (2000). Students' language learning preferences. Teaching English as a Second or Foreign Language, 4(3), 1-15. http://dx.doi.org/10.1016/j.sbspro.2013.09.159

Best, J. W. (1981). Research in Education. London: Prentice-Hall.

Cameron, L. (2001). Teaching language to children. Cambridge: Cambridge University.

Catalan, R. (2003). Sex differences in L2 vocabulary learning strategies. Applied Linguistics, 13(1), 54-77. http://doi.org/10.1111/1473-4192.00037

Carter, R., \& McCarthy, M. (1988). Vocabulary and language teaching. London: Longman.

Crystal, D. (1997). English as a global language. Cambridge: Cambridge University Press.

Cunningsworth, A. (1995). Choosing your course book. Oxford: Heinemann

EF English Proficiency Index (2013, Nov). Comparing English skills between countries - EF EPI. Retrieved on 2014-02-20, from http:// www.ef,com/epi.

Fan, M. Y. (2003). Frequency of use, perceived usefulness, and actual usefulness of second language vocabulary strategies: A study of Hong Kong learners. The modern Language Journal, 87(2), 222-241. http://doi.org/10.1111/1540-4781.00187

Gairns, R. \& Redman, S. (1986). Working with words. CUP.

Ghada, S. (2011). A match or mismatch between teacher and teacher learning style preferences. International Journal of English Linguistics, 1(1), 162-172. 
Gu, P. Y. \& Johnson, R. K. (1996). Vocabulary learning strategies and language learning outcomes. Language Learning, 643-679. http://dx.doi.org/10.1111/j.1467-1770.1996.tb01355.x

Hamzah, M. \& Kafipour, R \& Abdullah, S.K. 2009. Vocabulary learning strategies of Iranian undergraduate EFL students and its relation to their vocabulary size. European Journal of Social Science, 11, 39-50.

Hu, M. \& Nation, P. (2000). Unknown vocabulary density and reading comprehension. Reading in a Foreign Language. 13(1), 403-430.

Intaraprasert, C. (2004). ESE students and vocabulary learning strategies: A preliminary investigation. Unpublished research, Suranaree University of Technology, Nakhon Ratchasima, Thailand.

Kocic, A. (2008). The problem of synforms (similar lexical forms). Linguistics and Literature, 6(1), 51-59.

Komol, T. \& Sripetpun, W. (2011). Vocabulary learning strategies employed by undergraduate students and its relationship to their vocabulary knowledge. The $3 \mathrm{rd}$ International Conference on Humanities and Social Science, 1-18.

Laufer, B. (1988). 'The concept of synforms 'similar lexical forms' in L2 vocabulary acquisition'. Language and Education, 3, 113-132.

Laufer, B. (1990). 'Sequence' and 'order' in the development of L2 lexis. Applied Linguistics, 11, 281-296. http://dx.doi.org/10.1093/applin/11.3.281

Laufer, B. (1998). The development of passive and active vocabulary in a second language: Same or different? Applied Linguistics, 12, 255-271.

Laufer, B., \& Paribakht, T. S. (1998). The relationship between passive and active vocabularies: Effects of language learning context. Language Learning, 48(3), 365-391. http://dx.doi.org/10.1111/0023-8333.00046

McCarthy, M. (1990). Vocabulary. Oxford: Oxford University Press.

McCarthy, M. (1998). Vocabulary and language Teaching. New York: Longman.

Nandy, M. (1994). Vocabulary and grammar for G.C.E. "O" level English. Singapore: Composite Study Aids.

Nation, P. (2001). Learning vocabulary in another language. Cambridge: Cambridge University Press.

Nation, P. \& Beglar, D. (2007). A vocabulary size test. The Language Teacher, 31(7), 9-13.

Nation, P. \& Meara, P. (2002) Vocabulary. In N. Schmitt (ed.), An Introduction to Applied Linguistics Edward Arnold, 35-54.

Oxford, R. (1990). Language learning strategies: What every teacher should know. Boston: 
Newbury House.

Oxford R., \& Nyikos, M. (1989). Variables affecting choice of language learning strategies by university students. The Modern Language Journal, 73, 291-300. http://dx.doi.org/10.1111/j.1540-4781.1989.tb06367.x

Ratner, B. (2011). The correlation coefficient: Definition. Retrieved March 23, 2014, from http://www.dmstat1.com/ res/TheCorrelationCoefficientDefined.html.

Rattanavich, S. (2013). Comparison of Effects of Teaching English to Thai Undergraduate Teacher-Students through Cross-Curricular Thematic Instruction Program Based on Multiple Intelligence Theory and Conventional Instruction. English Language Teaching, 6(9), 1-18. http://dx.doi.org10.5539/elt.v6n9p1

Rubin, J. (1987). Study of cognitive processes in second language learning. Applied Linguistics, 11, 117-131.

Sarani, A and Kafipour, R. (2008). The study of Language Strategies Use by Turkish and Kurdish EFL University Students. Language Forum, 34(2). 137-188.

Sawangwaroros, B. (1984). American and British English. Phasa Parithat Journal, 4(2), 24-37.

Scharle, A. and Szabo, A. (2000). Learner autonomy: A guide to developing learner responsibility. Cambridge: Cambridge University Press.

Schmitt, N., (1997). Vocabulary learning strategies. In N. Schmitt, AND M. McCarthy, eds. Vocabulary: Description, Acquisition and Pedagogy. Cambridge University Press, 199-227.

Siriwan, M. (2007). English vocabulary learning strategies employed by Rajabhat University students. Unpublished Doctoral Dissertation, Suranaree University of Technology Nakhoratchasima, Thailand.

Sripetpun, W. (2000). The influence of vocabulary size on vocabulary learning strategies and vocabulary learning strategies. Unpublished Doctoral Dissertation. Victoria: La Trobe University, Australia.

Sokmen, A. (1997). Current trends in teaching second language vocabulary. In N. Schmitt \& M. McCarthy (eds.), Vocabulary: Description, acquisition, and pedagogy. Cambridge University Press. Spolsky, B. 1998. Sociolinguistics. Oxford University Press.

Sukkong, J. (2010). Learning achievement, retention, and attitudes towards English vocabulary learning of students taught games and conventional method. Unpublished Master Dissertation, Prince of Songkla University, Thailand.

Waldvogel, D. A, (2011). Vocabulary learning strategies among adult learners of Spanish as a foreign language. Unpublished Doctorial Dissertation. The University of Texas at Austin.

Waring, R. \& Nation, P. (1997). Vocabulary size, text coverage, and word lists. In N. Schmitt and M. McCarthy (eds.) Vocabulary: Description, Acquisition and Pedagogy. Cambridge University Press, Cambridge: 6-19. 


\section{Macrothink}

International Journal of English Language Education

ISSN 2325-0887 2014, Vol. 2, No. 1

Wenden, A. (1987). Conceptual Background and Utility. In A. Wenden and J. Rubin (Eds.), Learner Strategies in Language Learning (pp. 3-13). London: Prentice Hall International.

\section{Copyright Disclaimer}

Copyright reserved by the author(s).

This article is an open-access article distributed under the terms and conditions of the Creative Commons Attribution license (http://creativecommons.org/licenses/by/3.0/). 